\title{
Rewolucyjny realizm, rewolucyjny romantyzm i modelowi bohaterowie - utopia w literaturze maoistowskiej
}

DOI: http://dx.doi.org/10.12775/LC.2021.014

Streszczenie: W przypadku literatury maoistowskiej nie można mówić o realizacji utopii jako gatunku literackiego. Niektórzy badacze uważają jednak, że promowany przez Mao Zedonga rewolucyjny realizm i rewolucyjny romantyzm wprowadzily element utopijny do chińskiej literatury maoistowskiej. Według Mao literatura w nowym, socjalistycznym społeczeństwie miała pełnić rolę dydaktyczną i być narzędziem ideologicznej propagandy. Jako taka, musiała przedstawiać wzorce postaci i zachowań, oferować gotowe rozwiązania dylematów moralnych. Zgodnie z wytycznymi Mao, literatura tego okresu miała przedstawiać wprowadzanie w życie kampanii politycznych, które naprawiały istniejący wcześniej feudalny porządek społeczny, wprowadzały do społeczeństwa harmonię, ład i sprawiedliwość. Utwory literackie tego okresu miały przedstawiać wyidealizowanych bohaterów, którzy postawieni przed realnymi problemami przyjmują właściwą postawę i podejmują jedyną słuszną decyzję. Artykuł ma na celu przedstawienie, jaką rolę literatura pełniła w maoistowskiej propagandzie oraz jak realizowane w niej były utopijne koncepcje Mao. Przez przytoczenie przykładów konkretnych utworów autorka postara się również wskazać konkretne wzorce postaci i sposoby przedstawienia idealnego społeczeństwa.

Słowa kluczowe: literatura maoistowska, romantyzm rewolucyjny, realizm rewolucyjny, modelowi bohaterowie

\footnotetext{
* Asystent w Zakładzie Japonistyki i Sinologii na Uniwersytecie Jagiellońskim. Główny obszar jej badań to chińska literatura socrealistyczna.

E-mail: maria1.jarosz@uj.edu.pl | ORCID: 0000-0003-2214-4091.
} 


\title{
Revolutionary Realism, Revolutionary Romanticism, and Model Heroes: Utopia in Maoist Literature
}

\begin{abstract}
In the case of Maoist fiction, one cannot talk about utopia in the narrow sense. Some scholars, however, argue that revolutionary realism and revolutionary romanticism, promoted by Mao Zedong, did introduce utopian elements to Maoist literature. According to Mao Zedong, in the new socialist society literature was supposed to be educational and serve as a tool of ideological propaganda. As such, literature was required to show the exemplary figures and behaviors, as well as offer ready solutions to moral dilemmas. According to Mao's instructions, literature from this period was supposed to describe the process of implementing his policies, as they were destroying the previous feudal system and introducing harmony, order and justice into the society. Literary works from this era were to present idealized characters, that, when faced with real life problems, would always make the only right decision. This article aims at showing the role of literature in the Maoist propaganda and the ways in which Mao's utopian visions were reflected in literary works. Through discussing examples from particular novels the author will also try to draw attention to certain categories of characters and the way of creating the fictional ideal society.
\end{abstract}

Keywords: Maoist literature, revolutionary romanticism, revolutionary realism, model characters

\section{Czy utopia jest możliwa w literaturze maoistowskiej?}

\section{We}

wstępie do swojej książki, Stary wspaniały świat. O utopiach pozytywnych i negatywnych, Andrzej Juszczyk (2014: 11) twierdzi, że utopię można rozumieć na trzy sposoby. Za Karlem Manheimem nazywa utopię „odrębnym od innych sposobem myślenia”, który wynika z niezgody na otaczającą rzeczywistość. Jest to najszersze rozumienie utopii, będącej rodzajem „refleksji społecznej, politycznej, nawet filozoficznej, której istotną cechą jest wytwarzanie projektów gwarantujących lepszą przyszłość dla ludzi” (ibid.: 12). Drugim, węższym rozumieniem utopii jest „konkretny projekt organizacji społeczeństwa, występujący w formie literackiej lub realnie wcielany w życie” (ibid.). Za Michałem Łuczewskim Juszczyk (ibid.) podaje cechy tak rozumianej utopii: dokładność, radykalna niezgoda na świat, brak analizy aktualnych instytucji, maksymalne wymaganie całkowitej realizacji, jedyność, powszedniość, wieczność i maksymalne szczęście ludzi jako ich cel. Juszczyk przytacza też za Jerzym Szackim dziewięć założeń utopii według Chada Walsha: człowiek jest z założenia dobry, jako istota plastyczna może się zmieniać, jest rozumny i może stawać się rozumniejszy, pomyślność jednostki nie stoi w sprzeczności z pomyślnością społeczeństwa, liczba możliwości co do przyszłości jest ograniczona i są one przewidywalne, celem jest zapewnienie powszechnego szczęścia, szczęście nie może być nużące, istnieją sprawiedliwi władcy, utopia nie stanowi zagrożenia dla wolności (ibid.: 13). 
Utopia może być wreszcie rozumiana jako zjawisko literackie. Według Juszczyka (ibid.: 25) jedną z najważniejszych cech konstytutywnych utopii jako gatunku literackiego jest izolacja świata przedstawionego zarówno $\mathrm{w}$ aspekcie przestrzennym, jak i czasowym. Warunkiem istnienia utopii jest zatem jej nieistnienie w rzeczywistości pozaliterckiej (ibid.: 26).

Biorąc pod uwagę powyższe kryteria utopii, zwłaszcza utopii jako zjawiska literackiego, należałoby za Koon-ki Ho stwierdzić, że niemożliwym było tworzenie utopii za czasów Mao Zedonga (Ho 1997: 197). Skoro jednym z głównych założeń utopii jest niezgoda na zastaną rzeczywistość i jej krytyka, zrozumiałe jest, że takie utwory nie mogły być tolerowane przez komunistyczne władze Chińskiej Republiki Ludowej (ibid.: 197). Rolę literatury i sztuki w komunistycznych Chinach określił Mao Zedong już w 1942 roku, w dwóch przemówieniach wygłoszonych na Konferencji Literatury i Sztuki w Yan’anie. Za Leninem Mao nazwał literaturę i sztukę „śrubami w maszynie rewolucji”, zmieniając je w narzędzia propagandy. Mao zdefiniował też, jak powinny wyglądać relacje między sztuką i polityką. W mowie zamykającej całą konferencję powiedział, że „sztuka musi być podporządkowana interesom klasowym i interesom partyjnym, musi być podporządkowana politycznym wymaganiom tej klasy i partii, która w okresie rewolucji ma spełnić rewolucyjne zadanie" (Mao 1950: 37). Poruszył także temat kryterium oceny dzieła sztuki. Według Mao istnieją dwa takie kryteria - polityczne i estetyczne. Biorąc pod uwagę rolę, jaką miała pełnić sztuka w nowych Chinach, Mao stwierdził, że chociaż oba kryteria są ważne i należy zachować między nimi równowagę, to jednak kryterium polityczne zawsze powinno być nadrzędne wobec estetyki. Mao ograniczył więc rolę literatury do promowania działań partii, jednocześnie odbierając całkowicie rację bytu literaturze apolitycznej, nie mówiąc o literaturze krytykującej ówczesne władze. Postulaty Mao dotyczące miejsca literatury i sztuki w nowym państwie zostały potwierdzone podczas I Ogólnochińskiego Zjazdu Pracowników Literatury i Sztuki (Markowa 1980: 13).

Zgodnie $\mathrm{z}$ teorią Mao Zedonga rolą literatury było zatem promowanie jego wizji w chińskim społeczeństwie, a przede wszystkim popularyzowanie działań partii wśród mas ludowych - robotników, chłopów i żołnierzy. Amerykański historyk, Maurice Meisner, już w 1971 roku w swoim artykule „Maoist Utopianism and the Future of Chinese Society” dokonał analizy polityki przewodniczącego Mao, podkreślając jej utopijne elementy. Podobną koncepcję wysunął Douwe Fokkema w swojej książce Perfect Worlds. Utopian Fiction in China and the West (2011). Obaj badacze znajduja elementy utopijne w wizji politycznej Mao Zedonga, szczególnie w kampaniach podejmowanych pod koniec lat 50. i w latach 60 ., takich jak Wielki Skok Naprzód czy tworzenie komun ludowych.

Skoro więc literatura miała promować politykę przewodniczącego Mao, a jego polityczna wizja zawierała elementy utopijne, ergo literatura powstająca w czasach Mao musiała ucieleśniać jego utopijne pomysły, chociaż trzeba podkreślić, że ówczesne utwory literackie nie były oczywiście utopiami w znaczeniu gatunku literackiego. Przedstawienie realizacji utopijnej wizji Mao w wyidealizowanej fikcyjnej rzeczywistości możliwe było przez wprowadzenie nowej metody twórczej zaproponowanej przez Mao Zedonga - połączenia realizmu rewolucyjnego i romantyzmu rewolucyjnego (Markowa 1980: 29, 32). Innym zabiegiem, który również przyczynił się do tworzenia utopijnej wizji w utworach z lat 50. i 60 ., było kreowanie tzw. modelowych bohaterów, mających być wzorem do naśladowania dla chińskiego czytelnika (Ho 1997: 197). 
Można zatem stwierdzić, że chociaż próżno szukać w literaturze maoistowskiej realizacji utopii jako gatunku literackiego, pisarze tworzący w tym okresie wprowadzali do swoich utworów elementy utopii społecznej. W maoistowskich Chinach literatura miała jedno zadanie - promować wśród mas ludowych poglądy przewodniczącego Mao, przedstawiając je w jak najlepszym świetle. Biorąc zaś pod uwagę, że jego wizje przyszłości zdecydowanie nosiły znamiona utopijności, należy spodziewać się, że tym bardziej utopijne było jej odzwierciedlenie w literaturze.

\section{Utopijna wizja rewolucji według Mao Zedonga}

Rewolucje z reguły zainspirowane są utopijną wizją porządku społecznego. Zgodnie z teorią George’a Lichtheima wszystkie cywilizacje zbudowane są na utopijnych przesłankach, które chociaż nigdy nie zostają zrealizowane, gwarantują postęp (Meisner 1971: 536). W przypadku niemal każdej rewolucji można zauważyć pewną prawidłowość. Nawet jeżeli rewolucja odnosi sukces, to jej wynik jest zupełnie różny od początkowej utopijnej wizji, która zostaje wypaczona przez proces instytucjonalizacji (ibid.: 536). Po pierwszej burzliwej fazie rewolucji następuje proces budowania porządku i nowego ładu społecznego. Chińska rewolucja komunistyczna znacznie różni się od zaprezentowanego powyżej wzorca, ponieważ wraz z rozwojem rewolucji utopijne dążenia jej przywódcy, Mao Zedonga, zamiast osłabnąć, uległy nasileniu (ibid.: 537).

Przed rokiem 1949, czyli przed ustanowieniem Chińskiej Republiki Ludowej, wizja Mao nie cechowała się nadmierną oryginalnością. Głosił typowe marksistowskie slogany, a perspektywa nowego porządku społecznego była bardzo ogólna (ibid.: 541). Rozwój gospodarczy i społeczny w latach 1949-1955 przebiegał według przewidywalnego i typowego dla późniejszego etapu rewolucji schematu instytucjonalizacji i biurokratyzacji. Mao nadal głosił wizję idealnego, bezklasowego społeczeństwa, ale rewolucyjny zapał został ostudzony przez żmudne dążenie do rozwoju gospodarczego i przemysłowego. Bezklasowe społeczeństwo nadal stanowiło cel Mao, lecz był on dalekosiężny, jego realizacja wymagała czasu i przygotowań (ibid.: 542-543).

Wyjątkowe w chińskiej rewolucji komunistycznej jest to, że po ustanowieniu instytucji i porządku politycznego nastąpiło odrodzenie rewolucyjnego utopizmu (ibid.: 544). Impulsem stała się właśnie stale rozwijająca się biurokracja, która chociaż miała pomóc w budowaniu bezklasowego społeczeństwa, sama stała się klasą uprzywilejowanych urzędników (ibid.: 544). Mimo że celem rewolucji była „dyktatura mas ludowych”, w procesie instytucjonalizacji powstały dwie uprzywilejowane grupy: elita polityczna i elita technologiczna, które de facto skupiały władzę i wpływy. Meisner zauważa, że powodem „niecierpliwości” Mao w realizacji jego utopijnych wizji było nie tyle to, że rozwój społeczeństwa następował zbyt wolno, ale że zaczął iść w zupełnie odwrotnym kierunku, tworząc zinstytucjonalizowany podział między pracą intelektualną a fizyczną, między miastem i wsią (ibid.: 545). Mao zaczął więc głosić utopijną i populistyczną wizję mas ludowych przejmujących kontrolę nad instytucjami. 
Pierwszym efektem rosnącej utopijności dążeń Mao było znaczne przyspieszenie kolektywizacji w 1955 roku (ibid.: 545-546). Warto zauważyć, że w 1955 roku w Chinach było jedynie 500 tzw. zaawansowanych spółdzielni, a rok później - już 753 tysiące (Lin 1990: 1228-1252). Ponad 90 procent chłopów dołączyło do spółdzielni do końca 1956 roku (Ladejinsky 1957: 91-104). Utopizmem w pełnym wymiarze była najsłynniejsza kampania gospodarcza Mao Zedonga - Wielki Skok Naprzód (Meisner 1971: 546; Fokkema 2011: 321-322). Tym samym w 1958 roku utopijne dążenia Mao, których realizacja, jak wcześniej przewidywano, miała być rozciągnięta na wiele lat, musiały być zrealizowane natychmiast i jako takie zaczęły poważnie zagrażać stabilności biurokracji, podważając nie tylko jej autorytet, ale także jej zasadność (Meisner 1971: 546-548). Kulminacją „wiecznej rewolucji” Mao była rewolucja kulturalna, której celem był natychmiastowy i brutalny sprzeciw wobec elit, biurokracji, a nawet aparatu partyjnego.

Tym, co różniło utopijną wizję Mao Zedonga od marksizmu w czystej postaci, było niemal całkowite pominięcie ograniczeń społecznych, ekonomicznych i historycznych (ibid.: 551). Przykładem tego sposobu myślenia może być użyte przez Mao w 1958 r. określenie chińskich mas ludowych jako „biednych i pustych” (Fokkema 2011: 322). Maoistowska wizja chłopów, robotników i żołnierzy jako swoistej chińskiej wersji arystotelesowskiej tabula rasa pozwoliła na tak daleko idącą i natychmiastową realizację jego utopijnych dążeń. Fokkema (2011: 322) zauważa, że utopijne wizje (jak chociażby idea wielkich wspólnych jadalni) z dzieł Tomasza More’a czy Nikołaja Czernyszewskiego stały się rzeczywistością na chińskiej wsi. Jednak wraz z nadejściem Wielkiego Głodu w 1958 roku myśl Mao Zedonga doprowadziła do głodowej śmierci milionów chińskich chłopów (ibid.: 322). Chociaż utopijna wizja zmieniła się w dystopijną rzeczywistość, to jako narzędzie propagandy literatura maoistowska nadal przedstawiała wyidealizowany obraz chińskiego społeczeństwa.

\section{Realizm socjalistyczny a realizm rewolucyjny i romantyzm rewolucyjny. Modelowi bohaterowie}

Podstawową metodą twórczą w literaturze socjalistycznej jest zaproponowany przez Maksima Gorkiego realizm socjalistyczny (Markowa 1980: 30). Fokkema (2011: 324-325) nazwał ten kierunek hybrydą, ponieważ z jednej strony promował on realistyczną i wierną prawdzie historycznej reprezentację rzeczywistości, a z drugiej strony musiał pozwalać literaturze na spełnianie jej najważniejszej roli - kształtowania i edukowania mas w duchu socjalizmu. Swietłana Markowa (1980: 31), opisując socrealizm, mówi z kolei, że jest to połączenie realistycznej analizy istniejącej rzeczywistości z romantyczną perspektywą przyszłości.

W Chinach realizm socjalistyczny pojawił się już w latach 30. XX wieku. Po raz pierwszy użył tego terminu jeden z czołowych twórców chińskiej teorii literackiej epoki maoizmu, Zhou Yang, już w 1933 r. w artykule „O »realizmie socjalistycznym « i »romantyzmie 
rewolucyjnym «"1 (Yang 1996: 88). W latach 30. socjalizm rewolucyjny miał jednak ograniczony zasięg i stał się popularny dopiero w latach 40. (ibid.: 89). Mao Zedong podkreślił rolę realizmu socjalistycznego w chińskiej literaturze i sztuce w swoich przemówieniach podczas Konferencji Literatury i Sztuki w Yan'anie w 1942 r. Warto jednak zauważyć, że Mao użył sformułowania „realizm proletariacki”, już od początku nieco dystansując się od radzieckiego terminu. Użyte przez Mao określenie zostało jednak zamienione na „realizm socjalistyczny” w ponownym wydaniu jego przemówień z 1953 roku (Markowa 1980: 31; Fokkema 2011: 326)

Realizm socjalistyczny był w Chinach najważniejszym kryterium literackim przez większą część lat 50. Krytyka socrealizmu jako metody twórczej zaczęła się pojawiać w 1956 roku wraz z rosnącym sceptycyzmem wobec Stalina i samego Związku Radzieckiego (Yang 1996: 90). Rozłam między ZSRR i Chińską Republiką Ludową spowodował, że chińscy przywódcy chcieli odciąć się również od radzieckiej teorii literackiej. Do krytyki socrealizmu przyczynił się jednak nie tylko znaczny wzrost nacjonalizmu w chińskiej polityce, ale także stale rosnący kult Mao oraz coraz bardziej utopijny charakter jego wizji (Markowa 1980: 32). Wspomniany już wcześniej Zhou Yang otwarcie stwierdził, że socrealizm wyklucza kreatywność pisarzy i nie dopuszcza do głosu romantyzmu. Jednocześnie dodał jednak, że mimo niedociągnięć realizm socjalistyczny nadal powinien być kierunkiem dla chińskiej literatury i sztuki; nie można całkowicie z niego zrezygnować (Yang 1996: 90).

W 1958 roku Mao Zedong w czasie swojego przemówienia na konferencji powiedział, że chińska poezja powinna uosabiać połączenie realizmu i romantyzmu (ibid.: 91). Pierwszy raz oficjalnie o połączeniu realizmu rewolucyjnego i romantyzmu rewolucyjnego napisał jeszcze w tym samym roku Zhou Yang (ibid.: 5) w swoim artykule „Nowe pieśni ludowe otworzyły nową drogę dla poezji", mówiąc, że jest to teoria wysunięta przez przewodniczącego Mao. Sama idea połączenia realizmu i romantyzmu pojawiła się już znacznie wcześniej. Mao mówił o rewolucyjnym romantyzmie już w 1939 roku, ponadto sam od lat korzystał z tej metody twórczej we własnej twórczości poetyckiej. Zhou Yang natomiast w 1933 roku zaznaczył, że nie należy przeciwstawiać sobie realizmu i romantyzmu (1996: 91).

Na przełomie lat 50. i 60. połączenie realizmu rewolucyjnego i romantyzmu rewolucyjnego zastąpiło więc socrealizm i stało się wiodącą metodą twórczą w literaturze maoistowskiej. W 1960 roku Zhou Yang (1960: 29-30) określił tę metodę jako „dynamiczne połączenie rewolucyjnego ducha $\mathrm{z}$ realistycznym ujęciem przejawów życia oraz dialektyczne połączenie w sztuce dwóch metod twórczych - realizmu i romantyzmu” (tłum. za: Markowa 1980: 29-30). Innymi słowy było to połączenie socjalistycznej rzeczywistości i komunistycznych ideałów (ibid.: 94), a tak naprawdę pozwoliło na odejście od realizmu i coraz dalej idącą idealizację życia pod dyktando ideologii komunistycznej. Yang Lan (1996: 96) zauważa, że połączenie realizmu rewolucyjnego i romantyzmu rewolucyjnego spowodowało, że bardzo silna tendencyjność chińskiej literatury jeszcze wzrosła, ponieważ ta metoda

Należy zaznaczyć, że znaczenie terminu „romantyzm” w sformułowaniu „romantyzm rewolucyjny” różni się od "romantyzmu” jako epoki w historii literatury. „Romantyzm” (z chińskiego langman zhuyi) oznacza tutaj trend w literaturze chińskiej, w ramach którego na pierwszy plan wysuwają się elementy romantyczne. Chiński termin geming xianshi zhuyi he geming langman zhuyi xiang jiehe 革命现实主义和革命浪漫主义相结合 tłumaczony jest w pracach anglojęzycznych na "the combination of revolutionary realism and revolutionary romanticism” (Yang 1996: 96), a w pracach tłumaczonych na język polski już w 1980 r. przełożony został na „połączenie rewolucyjnego realizmu i rewolucyjnego romantyzmu" (Markowa 1980: 29). 
polegała de facto na podniesieniu znaczenia romantyzmu rewolucyjnego. Już w 1942 roku sam Mao (1991: 861) powiedział, że „życie, przedstawione w dziełach literatury i sztuki, może, a nawet powinno być na wyższej płaszczyźnie. Powinno być bardziej intensywne, bardziej skoncentrowane, bardziej typowe, bliższe doskonałości i tym samym bardziej uniwersalne niż prawdziwe" ${ }^{2}$. Jeszcze przed wprowadzeniem romantyzmu rewolucyjnego i realizmu rewolucyjnego do chińskiej twórczości literackiej Mao uważał, że świat przedstawiony w dziełach literackich powinien być lepszy, bliższy ideałowi niż rzeczywistość. Romantyzm rewolucyjny dopuścił natomiast, znacznie bardziej niż socrealizm, idealizację rzeczywistości w celu dopasowania jej do określonych celów politycznych czy ideologicznych. Tym samym literatura stała się doskonałym narzędziem do promowania utopijnych wizji Mao Zedonga. Dziełom literackim powierzono więc zadanie przedstawiania idealnych rezultatów, jakie miały wyniknąć z realizacji tych planów.

$\mathrm{Z}$ nową metodą twórczą powstałą z połączenia realizmu rewolucyjnego i romantyzmu rewolucyjnego oraz rosnącą utopijnością wizji Mao Zedonga wiązało się wprowadzenie do chińskiej literatury tzw. modelowych bohaterów. Fokkema (2011: 328) zwraca uwagę na to, że właśnie na początku lat 60. znacznie nasilił się kult „bohaterów” - modelowych robotników, żołnierzy czy przedstawicieli kadr partyjnych. Postaci takie jak Zhang Side, Lei Feng czy Ouyang Hai kreowane były przez KPCh na wzorcowych rewolucjonistów, lojalnych wobec marksizmu i gotowych oddać życie w imię rewolucji (ibid.: 328).

Wraz z narastającym kultem bohaterów rewolucji, pojawiła się presja, aby literatura przedstawiała również heroiczne czyny bojowników rewolucji. Miała ona być narzędziem propagandy i edukować masy ludowe, pełnić rolę swoistego „podręcznika życia”. Powinna więc pokazywać realne zmagania i problemy - walkę z wstecznymi poglądami, wojnę z Japonią, proces przeprowadzania reform i kolektywizacji itd. Jednak aby odpowiednio spełniać swoje zadanie, musiała również dawać czytelnikom odpowiedź na pytanie, jaką postawę powinni przyjąć w obliczu trudności - jak walczyć z obszarnikami lub Japończykami, jak przekonać innych chłopów do wzięcia udziału w kolektywizacji, jak należycie służyć rewolucji. Odpowiedzią na te pytania było właśnie kreowanie „modelowych bohaterów”, którzy stawiając czoła realnym problemom, zawsze przyjmowali idealne postawy (Bi 2007: 37).

W 1960 roku na III Ogólnochińskim Kongresie Pracowników Literatury i Sztuki Zhou Yang wygłosił przemówienie zatytułowane Droga socjalistycznej literatury i sztuki w Chinach. W swoim wystąpieniu nie tylko podkreślił rolę realizmu rewolucyjnego i romantyzmu rewolucyjnego, ale także potrzebę tworzenia w sztuce modelowych, heroicznych bohaterów, będących z jednej strony uosobieniem rewolucyjnych, komunistycznych ideałów, z drugiej, przynajmniej według Zhou Yanga (1960: 36), odbiciem rzeczywistego bohaterstwa i heroizmu chińskich rewolucjonistów, robotników i żołnierzy.

Realizm socjalistyczny również promował przedstawianie w literaturze postaci uosabiających cechy idealnych rewolucjonistów - chłopów-aktywistów, oddanych komunistów czy odważnych żołnierzy. Pozwalał jednak również na tworzenie „przeciętnych” i „wstecznych" bohaterów. Z jednej strony miało to na celu utrzymanie pozorów realizmu, z drugiejpodkreślenie kontrastu między idealnymi rewolucjonistami i resztą bohaterów (Yang 1996:

\footnotetext{
2 Tłumaczenie autorki z języka chińskiego. Polskie tłumaczenie (Mao Tse-tung. O zadaniach artysty i pisarza. Tłum. W. Jedlicka, M. Skibniewska, Warszawa 1950) jest niedokładne i nie oddaje znaczenia oryginału.
} 
97). Wprowadzenie realizmu rewolucyjnego i romantyzmu rewolucyjnego wykluczało natomiast skupianie się na kreacji innych kategorii postaci - idealni, modelowi bohaterowie mieli być w centrum, wszystkie inne postaci miały stanowić jedynie tło dla ich historii. Nie dawało to więc pisarzom możliwości tworzenia wiarygodnych i autentycznych bohaterów, którzy często stawali się jednowymiarowi. Modelowi bohaterowie byli więc bardziej uosobieniem cech typowych dla danej kategorii niż pełnowymiarowymi postaciami (Hsia 1963: 123).

Właśnie to stało się powodem krytyki realizmu rewolucyjnego i romantyzmu rewolucyjnego. W 1962 roku Shao Quanlin wysunął koncepcję „przeciętnych bohaterów”, przekonując pisarzy, aby zaczęli tworzyć postaci mniej wyidealizowane i bliższe rzeczywistości. Szybko jednak jego postawa spotkała się ze zmasowaną krytyką zwolenników nowej metody twórczej, a sam Shao Quanlin oraz kojarzeni z nim pisarze (m.in. Zhao Shuli) zostali poddani prześladowaniom (Markowa 1980: 202-205, 217). Jeszcze na początku lat 60. Zhou Yang twierdził, że chociaż w literaturze trzeba ukazywać modelowych, heroicznych bohaterów, nie można ich deifikować, nie mogą być idealni, pozbawieni realnych cech. Najważniejsze, aby uosabiali kluczowe dla rewolucji ideały, aby pokazywać ich niezwykłe zdolności i osiągnięcia, można jednak dopuścić pewne wady czy niedociągnięcia (Yang 1996: 97).

Całkowita idealizacja modelowych bohaterów nastąpiła dopiero w czasie rewolucji kulturalnej, co widoczne jest szczególnie w sztukach wzorcowych promowanych przez Jiang Qing (Fokkema 2011: 329). Chociaż mogłoby się wydawać, że właśnie z tego okresu pochodzić będzie najwięcej utopijnych obrazów w chińskiej prozie, to jednak w rzeczywistości był to czas, w którym praktycznie nie powstawały utwory zaliczane do fikcji literackiej. Jedynym powieściopisarzem, który tworzył w okresie rewolucji kulturalnej i który nadal cieszył się uznaniem władz, był Hao Ran. Oprócz jego powieści promowano także wspomniane powyżej wzorcowe opery. Poza tymi i paroma innymi nielicznymi wyjątkami pisarze albo zawiesili swoją działalność, albo porzucili literaturę piękną na rzecz literatury faktu. Wynikało to z niezwykle surowej kontroli ideologicznej ograniczającej całkowicie wolność artystyczną.

\section{Utopijne obrazy w chińskich utworach socrealistycznych}

Chociaż po wprowadzeniu do chińskiej twórczości literackiej nowej metody twórczej połączenia realizmu rewolucyjnego i romantyzmu rewolucyjnego - zdecydowanie wzrósł stopień idealizacji fikcyjnej rzeczywistości i bohaterów, to jednak przykłady utopijnych obrazów można znaleźć już we wcześniejszych utworach maoistowskich. Utopijność chińskiej literatury tego okresu wynikała bowiem przede wszystkim z roli literatury w nowym społeczeństwie - literatura miała być narzędziem propagandy, promować nowe kampanie polityczne i działalność KPCh. W tym celu obrazy przedstawiane w utworach literackich musiały być wystarczająco nęcące, aby zachęcić czytelników do poparcia inicjatyw partyjnych i aktywnej pomocy w ich implementacji. Za najważniejszych pisarzy socjalizmu realistycznego, metody twórczej poprzedzającej połączenie realizmu rewolucyjnego i romantyzmu 
rewolucyjnego, uważa się Zhao Shuli i Zhou Libo. W ich utworach, ukazujących proces realizacji reformy rolnej czy wczesny okres kolektywizacji, przedstawiony został wyidealizowany obraz chińskiego społeczeństwa, w którym każdy zna swoje miejsce w maszynie rewolucji i wie, jaką powinien grać rolę. Chociaż obraz społeczeństwa w powieściach socrealistycznych nie jest aż tak czarno-biały jak w późniejszych utworach, to jednak nietrudno jest wyodrębnić konkretne, powtarzające się kategorie bohaterów. Większość należących do tych kategorii postaci jest przedstawiona bardzo schematycznie, każda z nich jest wyposażona w podobny zestaw cech, który ma jej pomóc wykonać odpowiednie rewolucyjne zadanie.

Pierwszą z tych kategorii są przedstawiciele kadr partyjnych. W utworach opisujących reformę rolną członkowie partii mieli za zadanie zainspirować lokalnych chłopów do sprzeciwu wobec obszarników (właścicieli ziemskich), samoorganizacji i przeprowadzenia podziału ziem. Takimi działaczami partyjnymi są m.in. Xiao Chang (Przemiany w Lijiazhuangu [chiń. Lijiazhuang de bianqian 李家庄的变迁]) (Zhao 1950)3 czy Xiao Xiang i Xiao Wang (Huragan [chiń. Baofeng zhouyu 暴风骤雨]) (Zhou 1953). Są oni jednoznacznie pozytywnymi bohaterami - wiernymi i oddanymi partii rewolucjonistami. W większości sami pochodzą z rodzin chłopskich, mają doświadczenie w pracy na roli. Takim działaczem jest właśnie Xiao Wang z Huraganu, który „łatwo zawierał znajomość z chłopami, ponieważ sam kiedyś był parobkiem i rzeczywiście dobrze znał się na chłopskiej pracy" (Zhou 1953: 36). Nie uważa się za lepszego od chłopów i nawet decyduje się zamieszkać w domu jednego z najbiedniejszych mieszkańców wsi. Jedyną negatywną cechą Xiao Wanga może być nadmierny entuzjazm i niecierpliwość, ale są one hamowane przez jego przełożonego, Xiao Xianga.

Kolejną kategorią bohaterów są chłopi-aktywiści. Do nich należą m.in. Tiesuo (Przemiany w Lijiazhuangu), Wang Jinsheng, Wang Yumei (Sanliwan 三里湾) (Zhao 2009), a także Zhao Yulin, Guo Quanhai i Bai Yushan (Huragan). To właśnie oni odpowiadają na wezwanie działaczy partyjnych, inicjują samoorganizację i dążą do obalenia obszarników. Xiao Xiang, wypełniając jako wprowadzający podanie o przyjęcie do partii Zhao Yulina, opisał go tak: „Biedak, uczciwy, umie pracować, gotów wszystko poświęcić dla sprawy wyzwolenia robotników i chłopów" (Zhou 1953: 165). Podobnie można by opisać także innych chłopów-aktywistów z Huraganu oraz Tiesuo z Przemian ... Z kolei młodzi bohaterowie Sanliwan są zdeterminowani, aby przekonać swoje rodziny i mieszkańców wsi do wzięcia udziału w kolektywizacji.

Również postaci negatywne - obszarnicy, kolaboranci czy nacjonaliści - przedstawione są w tak samo schematyczny sposób. Trudno odróżnić od siebie Li Ruzhena z Przemian ... od Hana Laoliu (Hana Szóstego) z Huraganu. Obaj bohaterowie są jednoznacznie negatywni, wyzyskują chłopów, źle traktują wszystkich swoich podwładnych, kolaborują z Japończykami i nacjonalistami. Aby uczynić te postaci jeszcze bardziej zdemoralizowanymi, zarówno Zhao Shuli, jak i Zhou Libo ukazują swoich obszarników jako pożądliwych rozpustników. Mający dwie żony Han Laoliu porwał, torturował i wreszcie zabił córkę swojego parobka tylko dlatego, że nie chciała mu ulec.

Chociaż postaciom z utworów socrealistycznych daleko do modelowych bohaterów $\mathrm{z}$ ery realizmu rewolucyjnego i romantyzmu rewolucyjnego, to jednak tak daleko idąca

\footnotetext{
3 Zgodnie z dawnym sposobem transkrypcji fonetycznej: Przemiany w Liciaczuangu.
} 
kategoryzacja bohaterów jest przejawem idealizacji fikcyjnej rzeczywistości i przedstawionego w niej społeczeństwa. Również fabuła utworów z tego okresu jest bardzo schematyczna - w utworach poruszających temat reformy rolnej do wsi rządzonej przez wyzyskującego chłopów obszarnika przyjeżdżają działacze partyjni, którzy edukują chłopów, dają im impuls do samoorganizacji, która w efekcie prowadzi do egzekucji rzeczonego obszarnika; w utworach o kolektywizacji grupa aktywnych i postępowych chłopów skutecznie przekonuje swoich opornych i wstecznych sąsiadów do przyłączenia się komuny w imię idei socjalizmu.

Typowe dla socrealistycznych utworów są również duże zbiorowe sceny na końcu utworu przynoszące szczęśliwe zakończenie - zabieg, który szczególnie upodobał sobie Zhao Shuli (por. Małżeństwo Młodego Erheia [chiń. Xiao Erhei jiehun 小二黑结婚] $(1954)^{4}$, Przemiany $w$ Lijiazhuangu [1950]). Utwory z takim właśnie zakończeniem były przyjmowane bardzo pozytywnie przez masy ludowe, ale takie zakończenia były dowodem na idealizację rzeczywistości w chińskiej fikcji (Bai 2016: 97). Należy jednak pamiętać, że już w realizmie socjalistycznym ważniejsze od wierności realiom było promowanie ducha socjalizmu i idei rewolucji.

\section{Modelowi bohaterowie i utopijne motywy w literaturze maoistowskiej w ramach realizmu rewolucyjnego i romantyzmu rewolucyjnego}

Właśnie promowanie idei i ducha socjalizmu wpłynęło na dalej posuniętą idealizację rzeczywistości w realizmie rewolucyjnym i romantyzmie rewolucyjnym. Stało się to możliwe dzięki nadaniu specjalnego znaczenia romantyzmowi, który stał się niemal nadrzędny wobec realizmu (sam realizm rewolucyjny niewiele różniłby się od socrealizmu). Doprowadziło to do jeszcze dalszej idealizacji bohaterów, schematyzacji fabuły i rzeczywistości. Najważniejszymi utworami realizmu rewolucyjnego i romantyzmu rewolucyjnego są Wielkie przemiany w górskiej wsi (chiń. Shanxiang jubian 山乡巨变) Zhou Libo, Pieśń mtodości (chin. Qingchun zhi ge 青春之歌) Yang Mo, Budowniczowie (chiń. Chuangye shi 创业史) Liu Qinga, Czerwone stońce (chiń. Hong ri 红日) Wu Qianga i wreszcie Złota droga (chiń. Jinguang dadao 金光大道) Hao Rana ${ }^{5}$. Głównymi bohaterami wszystkich tych powieści są właśnie modelowi bohaterowie, których heroiczne czyny pozwalają promować ducha socjalizmu.

\footnotetext{
${ }^{4}$ W polskim tłumaczeniu wydane pod tytułem Małżeństwo Siao Er-hej.

5 Tytuły w tłumaczeniu autorki z powodu braku polskiego przekładu. Warto zresztą zauważyć, że w latach 50. polskie tłumaczenia chińskich utworów w ogromnej większości dokonywane były za pośrednictwem języka rosyjskiego.
} 
Pieśń młodości Yang Mo została wydana w 1958 roku i promowana była jako idealny przykład zastosowania nowej metody twórczej - połączenia realizmu rewolucyjnego i romantyzmu rewolucyjnego - natychmiast stała się bestsellerem (McDougall et al. 1997: 243; Ban 2003: 472). Jest to powieść opowiadająca historię dorastania jednostki do świadomości rewolucyjnej. Akcja utworu toczy się w latach 1930-1935, w czasie narastającej okupacji japońskiej i rządów nacjonalistów. Główna bohaterka - Lin Daojing - jest córką właściciela ziemskiego i chłopki, którą zgwałcił. Lin ucieka od próbującej zmusić ją do małżeństwa macochy i jest bliska popełnienia samobójstwa, ale ratuje ją Yu Yongze, młody intelektualista, w którym dziewczyna się zakochuje (Ban 2003: 472-473). Lin odmawia jednak podjęcia narzucanej jej tradycyjnej roli żony i matki, mówiąc wprost: „Chcę być niezależna, chcę być częścią społeczeństwa jako wolny człowiek” (Yang 2012: 75) ${ }^{6}$. Na tajnym zebraniu Lin poznaje Lu Jiachuana - młodego komunistycznego aktywistę, który staje się nowym obiektem jej miłości i pozwala jej zerwać z burżuazyjną przeszłością. Dzięki niemu Lin angażuje się w działalność rewolucyjną i staje się przywódczynią studenckich protestów przeciwko biernej postawie Kuomintangu w wojnie z Japonią (Ban 2003: 472-473). Polityczne przebudzenie Lin nadaje jej życiu sens, pozwala marzyć o wielkich, doniosłych, heroicznych, rewolucyjnych czynach, jakich chciałaby dokonać. Inspiracją dla niej stają się napotkani komuniści - wspomniany już wcześniej Lu Jiachuan i Lin Hong, współwięźniarka Lin, która ponosi męczeńską śmierć w imię rewolucji. Bohaterka identyfikuje się z nimi, nawiązuje więź emocjonalną, ale jej uczucie do konkretnych działaczy bardzo szybko zostaje przeniesione na miłość do partii. W Pieśni młodości romantyczna miłość zlewa się ze świadomością polityczną, Yang Mo pokazuje, że można kochać politykę z taką samą pasją, jak drugą osobę, a czasem nawet bardziej fanatycznie (Ban 2003: 473-474). Znamiennym, nie tylko dla tej konkretnej historii, ale w ogóle dla realizmu rewolucyjnego i romantyzmu rewolucyjnego, staje się zdanie napisane przez Lin Daojing w liście miłosnym do Lu Jiachuana: „Przyjacielu, mimo moich zmartwień i trosk, jestem taka szczęśliwa! To Ty - to Partia, gdy się zgubiłam, wskazała mi właściwy kierunek" (Yang 2012: 211). Z punktu widzenia realizmu socjalistycznego historia Lin jest opowieścią o jednostce, która chce stać się podmiotem historii. Nie można jednak zignorować wszechobecnego w powieści romantyzmu. Zarówno C. T. Hsia (1963: 121), jak i Ban Wang (2003: 473) zwracają uwagę na rewolucyjną pasję zarówno głównej bohaterki, jak i przedstawionych w powieści komunistów. Wyeksponowane zostają emocje, energiczność, idealizm, bezwarunkowe oddanie rewolucji (ibid.: 473). Można tu przytoczyć chociażby scenę śmierci Lin Hong, w której młoda rewolucjonistka wynoszona ledwie żywa z celi wznosi jeszcze bojowy okrzyk: „Precz z reakcyjnym Kuomintangiem!”, a zaraz dołączają do niej kolejne głosy: „Niech żyje partia komunistyczna!”, „Komunizm jest niezwyciężony!” i „Towarzysze, pomścijcie nas!” (Yang 2012: 364). Warta uwagi jest też scena, w której Lin Daojing dowiaduje się, że jej wieloletnie marzenie wreszcie się spełniło i została przyjęta do Komunistycznej Partii Chin. Lin wzruszona patrzy na wiszące na ścianie obrazy przedstawiające pejzaże, które nagle zmieniają się w jej wyobraźni w wielką czerwoną flagę z sierpem i młotem, a bohaterka mówi: „Od dzisiaj całe swoje życie bezwarunkowo oddam partii, oddam je na ten największy, najszlachetniejszy cel...” (Yang 2012: 402). Po tych słowach Lin nie może już powstrzymać łez, ale w myślach zadaje sobie jeszcze pytanie, czy na świecie istnieje większe szczęście, czy istnieje coś szlachetniejszego

\footnotetext{
${ }^{6}$ Cytaty z Pieśni młodości zostały przetłumaczone przez autorkę z języka chińskiego.
} 
niż te łzy (Yang 2012: 402). Właśnie taka teatralność zachowań bohaterów powoduje dramatyzację, idealizację rzeczywistości, która w kontekście realizmu socjalistycznego byłaby śmieszna i sztuczna, jest natomiast częścią konwencji realizmu rewolucyjnego i romantyzmu rewolucyjnego.

Podobną pasję i dążenie do heroizmu można zauważyć w Czerwonym słońcu Wu Qianga. Fabuła tej powieści skupiona jest wokół oddziału armii komunistycznej, który, pokonany przez armię będących u władzy nacjonalistów w 1946 roku, kilka miesięcy później bierze odwet na swoich przeciwnikach. Hsia (1963: 129) zauważa, że tę historię czyta się niemal jak spis bohaterów i ich heroicznych dokonań. Posuwa się nawet do tego, że nazywa oddział armii komunistycznej „klubem wzajemnej adoracji dla bohaterów” (ibid.: 131). Największym z bohaterów jest dowódca oddziału, który w decydującej bitwie oddaje swoje życie w imię rewolucji. W swoich ostatnich chwilach mówi do swojego towarzysza, aby był posłuszny partii, aby doprowadził rewolucję do końca - prawdziwy bohater nawet w swoich ostatnich chwilach myśli o rewolucji (Wu 2004: 505). Warto zauważyć, że i w tej powieści, podobnie jak w Pieśni młodości, w niezwykle podniosłej scenie, w której młodzi żołnierze przyjmowani są do partii, nad ich głowami powiewa czerwona flaga $\mathrm{z}$ sierpem i młotem (ibid.: 539-540). Hsia (1963: 134) zwraca uwagę na sztuczność w kreacji bohaterów. Żołnierze w Czerwonym słońcu są przerysowani, „przybierają pozy” bohaterów. W konwencji realistycznej, a nawet w ramach socrealizmu nie można stosować takiego sposobu kreowania postaci, ponieważ zwyczajnie wydawaliby się zbyt śmieszni. Jednak podobnie jak w przypadku Pieśni młodości, tak i tutaj, metoda realizmu rewolucyjnego i romantyzmu rewolucyjnego pozwala na tak daleko idącą idealizację bohaterów. Nie mają oni już bowiem być odzwierciedleniem zwykłych ludzi - mają być ideałem, celem, do którego zwykli ludzie powinni dążyć.

Postępującą idealizację modelowych bohaterów można pokazać na przykładzie trzech postaci: Liu Yushenga z Wielkich przemian w górskiej wsi, Liang Shengbao z Budowniczych i Gao Daquana ze Złotej drogi.

Liu Yusheng, jeden z bohaterów wydanej w dwóch częściach (w 1958 i 1960 roku) powieści Zhou Libo - Wielkie przemiany w górskiej wsi, jest chłopem, który staje na czele kolektywu w tytułowej wsi (McDougall et al. 1997: 226). Jako chłopski aktywista Liu Yusheng łączy w sobie idealistyczne cechy socjalistycznego przywódcy z realistycznymi uczuciami zwykłych ludzi (Yang 1996: 101). Jest odważny, oddany sprawie rewolucji, gotowy do poświęceń. Nie tylko ratuje innego aktywistę, gdy ten próbuje popełnić samobójstwo, ale także sam ryzykuje własne życie, gdy wieś zostaje dotknięta przez powódź (ibid.: 226). Mimo swoich niezaprzeczalnych walorów i heroizmu, Liu Yusheng nie jest jeszcze bohaterem idealnym. Spotyka się z krytyką i obelgami ze strony innych chłopów (również pozytywnych bohaterów), zostaje zmuszony przez żonę do wzięcia rozwodu. Chociaż przedkłada interes kolektywu i działalność polityczną nad osobiste szczęście, nie przychodzi mu to łatwo i rozwód jest dla niego powodem wielkiego cierpienia (Yang 1996: 101).

Z podobnymi problemami spotyka się Liang Shengbao z Budowniczych Liu Qinga z 1960 roku (Liu pracował nad wydaniem drugiego tomu, ale przeszkodził mu w tym wybuch rewolucji kulturalnej w 1966 roku). Pierwsza część powieści skupia się na założeniu i rozwoju stowarzyszenia samopomocy, na którego czele stoi i którego inicjatorem jest właśnie Liang Shengbao. Druga część opowiada zaś o procesie kolektywizacji (Hong 2011: 115-116). W porównaniu do Liu Yushenga Liang Shengbao jest o wiele bardziej aktywny 
w ruchu rewolucyjnym, nie wykonuje jedynie poleceń, ale aktywnie i świadomie realizuje politykę partii (Yang 1996: 101). Ważne jest to, że mimo wysokiej świadomości politycznej, Liang jest całkowicie wierny partii i pokłada ufność w aparacie partyjnym. Podobnie jak Liu Yusheng Liang Shengbao również musi wybrać między osobistym szczęściem a interesem kolektywu i działalnością polityczną. Rezygnuje ze związku z Xu Gaixią, odtrąca ją, ponieważ małżeństwo z nią przeszkadzałoby mu w pracy na rzecz rewolucji (ibid.: 102). W sercu Lianga „szalał ogień - nie ogień miłości, ale ogień ideałów”, który sprawiał, że młodzi mężczyźni „zapominali jeść i spać, byli obojętni wobec kobiet”, a dla ideałów gotowi byli poświęcić nawet życie (Liu 2009: 78)7 . Kiedy Gaixia wyznaje Liangowi miłość, młody aktywista przez chwilę pragnie dać się ponieść uczuciom, ale już po chwili „rozsądek Shengbao jako członka partii komunistycznej pozwolił mu pokonać słabość, jakiej na każdym kroku ulegają istoty ludzkie. [... ] On [Liang] nie miał prawa być kapryśny!” (ibid.: 416). Chociaż Liang - bezinteresowny, lojalny, gotowy do poświęceń, optymistyczny, entuzjastyczny i dojrzały politycznie - podawany był jako przykład doskonale wykreowanego modelowego bohatera socjalistycznego, to jednak nie był jeszcze całkowicie pozbawiony wad. Jego uczucie do Xu Gaixi jest oparte początkowo na pociągu fizycznym, dopiero potem przeradza się w romantyczną fascynację. Chociaż oddaje własne ziarno innym chłopom, to jednak myśli o tym, jak ucierpi na tym jego własna rodzina. Ponadto, podobnie jak Liu Yusheng, spotyka się z niechęcią ze strony innych pozytywnych bohaterów - matka Xu Gaixi jest oddaną komunistką, ale nie chce mieć zięcia-aktywisty, który zaniedbywałby rodzinę na rzecz działalności politycznej (Yang 1996: 102). Obraz Liang Shengbao jest zdecydowanie wyidealizowany, ale nie jest on jeszcze całkowicie pozbawionym wad perfekcyjnym rewolucjonistą.

Takim bohaterem jest dopiero Gao Daquan ze Złotej drogi Hao Rana. Już samo jego imię Gao Daquan 高大全 znaczy „wysokość”, „wielkość”, „perfekcja” (ibid.: 103) i powinno dać czytelnikowi czytelną wskazówkę, jakiego bohatera powinien się spodziewać. Fabuła powieści skupia się na nowej kampanii - akcji „budowania fortun” - ogłoszonej po zakończeniu reformy rolnej w 1951 roku i mającej na celu podniesienie poziomu produkcji (ibid.). Gao jako jedyny działacz partyjny w wiosce sprzeciwia się realizowaniu tej kampanii, ponieważ uważa, że nie jest ona zgodna z duchem i zasadami socjalizmu. Świadomość polityczna Gao jest znacznie wyższa niż nie tylko Liu Yushenga i Liang Shengbao, ale także jego przełożonych, co usprawiedliwia jego niesubordynację. Sam, działając wbrew poleceniom lokalnych działaczy, organizuje chłopów, aby sprzeciwili się nowej kampanii. Należy zaznaczyć, że Złota droga została napisana w czasie rewolucji kulturalnej (1972 r.), kiedy to sam Mao Zedong nawoływał do obalania biurokracji i buntu wobec autorytetów w imię rewolucji i socjalizmu. Chociaż działania Gao powodują rozłam w rodzinie, on pozostaje niewzruszony, nie ma żadnych wątpliwości, że postępuje słusznie. W przeciwieństwie do Liu Yushenga i Liang Shengbao Gao jest nie tylko jednoznacznie chwalony i podziwiany przez wszystkich pozytywnych bohaterów, ale ma też pełne poparcie swojej żony, która widząc, jak ciężko jej mąż pracuje, postanawia jeszcze bardziej przyłożyć się do wykonywania domowych obowiązków. Gao Daquan jest idealnym rewolucjonistą swoich czasów - pozbawionym wad, niezależnym, odważnym, świadomym, kwestionującym partyjną hierarchię

\footnotetext{
7 Cytaty z Budowniczych zostały przetłumaczone przez autorkę z języka chińskiego.
} 
w imię wyższych ideałów, gotowym do poświęceń. W osobie Gao dokonuje się kulminacja idealizacji modelowych bohaterów.

\section{Zakończenie}

Sytuacja polityczna, w jakiej znaleźli się chińscy pisarze po wygranej komunistów i ustanowieniu Chińskiej Republiki Ludowej, nie sprzyjała tworzeniu utopii literackich. Wszechobecna cenzura i presja polityczna nie dawała pisarzom wystarczającej wolności artystycznej, nie pozwalała na tworzenie niezależnych, odbiegających od partyjnych wytycznych wizji państwa czy społeczeństwa. Mimo to można w utworach literackich epoki maoistowskiej znaleźć pewne motywy utopijne, które były niezbędne do przekształcenia literatury w skuteczne narzędzie propagandy.

Obecność elementów utopijnych w literaturze maoistowskiej wynika z wielu czynników. Pierwszym z nich jest rola literatury w ówczesnej propagandzie - skoro ma ona edukować i promować właściwe zachowania i postawy, musi kusić wizją idealnego ładu społecznego. Powstające w tym okresie utwory literackie przedstawiają chińskie społeczeństwo, w którym każdy ma do odegrania swoją rolę. Działacze partyjni i chłopi ukazani w literaturze tego czasu mają stanowić przykład, uczyć czytelników, jak należy działać na rzecz stworzenia idealnego socjalistycznego społeczeństwa.

Po drugie, utopijne wizje w fikcji literackiej tego okresu były odzwierciedleniem utopijnych idei przewodniczącego Mao, który dążył do ich realizacji w rzeczywistości, a literatura miała pokazywać, jak powinna przebiegać ich implementacja i jakie będą ich idealne rezultaty. Ówczesne utwory literackie pełne są przykładów wyidealizowanego procesu realizacji reformy rolnej czy kolektywizacji, kolektywizacji kończącej się zawsze stworzeniem komun ludowych, do których dobrowolnie dołączają wszyscy chłopi. Próżno jednak w literaturze z tego okresu szukać opisów rzeczywistych skutków tego procesu i Wielkiego Skoku Naprzód - chłopów zmuszonych do oddania swojej dopiero co wydartej obszarnikom ziemi, sprzeciwu wobec kolektywizacji czy wreszcie braków żywności i Wielkiego Głodu.

Dodatkowo nowe metody twórcze - zarówno połączenie realizmu rewolucyjnego i romantyzmu rewolucyjnego, jak i, chociaż w mniejszym stopniu, poprzedzający je realizm socjalistyczny - promowały przedstawianie wyidealizowanej wersji rzeczywistości w fikcji literackiej. Na idealizację konstruowanej rzeczywistości wpływ miało wreszcie kreowanie modelowych bohaterów, którzy mieli stanowić wzór do naśladowania. W literaturze maoistowskiej nie brakuje więc przykładów heroicznych żołnierzy, gotowych poświęcić życie w walce z Japończykami lub wojskami Kuomintangu; czy działaczy partyjnych - prawdziwych komunistów, dla których nie ma nic ważniejszego niż realizacja socjalistycznych ideałów i dążenie do urzeczywistnienia utopijnej wizji bezklasowego społeczeństwa.

Kulminacją idealizacji rzeczywistości w literaturze była rewolucja kulturalna. Nieliczne przykłady fikcji literackiej z tego okresu przedstawiają idealnych modelowych bohaterów perfekcyjnych, pozbawionych jakichkolwiek wad, z pełną świadomością polityczną, całkowicie oddanych idei rewolucji. Są to postaci całkowicie wyidealizowane, odczłowieczone, stanowią ideał nieosiągalny dla zwykłych śmiertelników. Tak daleko posunięta idealizacja jest poniekąd wypaczeniem postulatów Mao z Yan’anu, zgodnie z którymi literatura i sztuka 
powinny być blisko ludzi, opisywać życie mas ludowych, miały być „wynikiem pracy rewolucyjnego artysty, pracy mającej na celu odzwierciedlenie życia ludu” (Mao 1950: 28-29). Polityka Mao od okresu yanańskiego uległa jednak znacznym zmianom, a jego idee stawały się coraz bardziej utopijne. Rewolucja Kulturalna była apogeum utopijnych wizji Mao Zedonga, ale jednocześnie stanowi namacalny dowód tego, że te wyobrażenia wprowadzone w życie mogą skończyć się jedynie dystopijną rzeczywistością.

\section{Bibliografia}

Bai Chunxiang 2016. Zhao Shuli xiaoshuo de minjianhua xushi [Narracja ludowa w utworach Zhao Shuli]. Taiyuan: Beiyue wenyi chubanshe.

Ban, Wang 2003. „Revolutionary Realism and Revolutionary Romanticism: The Song of Youth” [Realizm rewolucyjny i romantyzm rewolucyjny: Pieśń młodości]. W: Joshua Mostow (red.). The Columbia Companion to Modern East Asian Literature. New York: Columbia University Press.

Bi Guangming 2007. „Shehui zhuyi lunli yu »shiqi nian« wenxue shengtai” [Etyka socjalistyczna i środowisko literackie okresu „siedemnastu lat”]. Nanfang wentan 5: 36-40.

Fokkema, Doewe 2011. Perfect Worlds. Utopian Fiction in China and the West [Idealne światy. Literatura utopijna w Chinach i na Zachodzie]. Amsterdam: Amsterdam University Press.

Ho, Koon-ki 1997. „Anti-utopian Novels in Contemporary Chinese Literature: The Utopian Dream and There Was a Country of Women Far Away" [Antyutopijne powieści we współczesnej literaturze chińskiej: Utopijny sen i Daleko stąd było państwo kobiet]. Oriens Extremus 2 (40): 197-216.

Hong, Zicheng 2011. A History of Contemporary Chinese Literature [Historia współczesnej literatury chińskiej]. Leiden, Boston: Brill.

Hsia, C.T. 1963. „Heroes and Hero-Worship in Chinese Communist Fiction” [Bohaterowie i kult bohaterów w chińskiej literaturze komunistycznej]. The China Quarterly 13: 113-138.

Juszczyk, Andrzej 2014. Stary wspanialy świat. O utopiach pozytywnych i negatywnych. Kraków: Wydawnictwo Uniwersytetu Jagiellońskiego.

Ladejinsky, Wolf 1957. „Carrot and Stick in Rural China” [Kij i marchewka na wiejskich obszarach Chin]. Foreign Affairs 1 (36): 91-104.

Lin, Yifu J. 1990. „Collectivization and China's Agricultural Crisis in 1959-1961” [Kolektywizacja i chiński kryzys rolniczy w latach 1959-1961]. Journal of Political Economy 6 (98): $1228-1252$.

Liu, Qing 2009. Chuangye shi [Budowniczowie]. Beijing: Zhongguo qingnian chubanshe.

Mao, Zedong (Mao Tse-tung) 1950. O zadaniach artysty i pisarza. Tłum. W. Jedlicka M. Skibniewska. Warszawa: Czytelnik. Spółdzielnia wydawniczo-oświatowa.

— 1991. „Zai Yan’an wenyi zoutanhui de jianghua” [Przemówienia na Forum Literatury i Sztuki w Yananie]. W: Mao Zedong xuanji, t. 3. Beijing: Renmin chubanshe.

Markowa, Swietłana D. 1980. Maoizm a inteligencja. Problemy i wydarzenia (1956-1973). Tłum. B. Szmiel. Warszawa: Państwowe Wydawnictwo Naukowe.

McDougall, B. S. [\&] Kam Louie 1997. The literature of China in the twentieth century [Literatura Chin w dwudziestym wieku]. New York: Columbia University Press.

Meisner, Maurice 1971. „Maoist Utopianism and the Future of Chinese Society” [Maoistowski utopizm i przyszłość chińskiego społeczeństwa]. International Journal 3 (26): 535-555.

Wu Qiang 2004. Hong ri [Czerwone słońce]. Beijing: Zhongguo qingnian chubanshe. 
Yang, Lan 1996. „»Socialist Realism《 versus »Revolutionary Realism plus Revolutionary Romanticism «” [„Realizm socjalistyczny” versus „realizm rewolucyjny plus romantyzm rewolucyjny"]. W: Hilary Chung (red.). The Party Spirit: Socialist Realism and Literary Practice in the Soviet Union, East Germany and China („Critical Studies”, 6). Amsterdam, Atlanta (GA): Rodopi.

Yang Mo 2012. Qingchun zhi ge [Pieśń młodości]. Beijing: Renmin wenxue chubanshe.

Zhao, Shuli (Czao Szu-li) 1950. Przemiany w Liciaczuangu. Tłum. Tadeusz Żeromski. Warszawa: Książka i Wiedza.

Zhao, Shuli (Czao Szu-li) 1954. „Małżeństwo Siao Er-hej”” Tłum. Maria Milecka. W: Natalia Billi (red.). Pewnej nocy. Nowele chińskie. Warszawa: Czytelnik.

— 2009. Sanliwan. Taiyuan: Beiyue wenyi chubanshe.

Zhou, Libo (Czou Li-po) 1953. Huragan. Tłum. Eleonora Romanowicz-Podolska. Warszawa: Czytelnik.

Zhou, Yang 1960. The Path of Socialist Literature and Art in China. Report Delivered to the Third Congress of Chinese Literary and Art Workers On July 221960 [Droga literatury i sztuki w Chinach. Raport przedstawiony na III Kongresie Pracowników Literatury i Sztuki 22 lipca 1960 r.]. Peking: Foreign Languages Press.

— 1990. „Xin minge kaitou le shige de xin daolu” [Nowe pieśni ludowe otworzyły nową drogę dla poezji]. W: Yang Guoliang [\&] Luo Junce (red.). 1990. Zhou Yang wenji [Dzieła zebrane Zhou Yanga]. Beijing: Renmin wenxue chubanshe. 